\title{
KEMAMPUAN MENULIS BAHASA INGGRIS SISWA MELALUI SELF-EDITING AND SELF-CORRECTING BERDASARKAN ANALISIS KESALAHAN GRAMATIKAL DAN KOSAKATA
}

\author{
Mathelda Obisuru ${ }^{1}$, Widyastuti Purbani ${ }^{2}$ \\ ${ }^{1}$ SMA Negeri 1 Kalabahi-Alor. Jalan Ade Irma Nasution No. 11, Kabupaten Alor, Indonesia. \\ ${ }^{2}$ Jurusan Pendidikan Bahasa Inggris, Universitas Negeri Yogyakarta. Jalan Colombo No. 1, \\ Karangmalang, Yogyakarta 55281, Indonesia. \\ * Korespondensi Penulis. Email: honey.dear93@yahoo.com, Telp: +6282134491199
}

\begin{abstract}
Abstrak
Penelitian ini bertujuan meningkatkan kemampuan menulis bahasa Inggris siswa melalui selfediting and self-correcting berdasarkan analisis kesalahan tata bahasa dan kosakata. Jenis penelitian ini adalah penelitian tindakan kelas. Data dikumpulkan melalui observasi dan dari tes menulis siswa. Penelitian dilakukan secara kolaboratif dalam dua siklus, dan setiap siklus terdiri dari perencanaan, pelaksanaan, observasi, dan refleksi. Setelah dilakukan tindakan self-editing and self-correcting dalam dua siklus, ditemukan adanya peningkatan kemampuan menulis bahasa inggris siswa. Peningkatan ini dapat dilihat dari adanya perbedaan hasil analisis kesalahan pada pra-tindakan, tindakan siklus I dan tindakan siklus II. Hasil analisis pra-tindakan menemukan 29,16\% memperoleh skor minimal 70, siklus I menemukan $60 \%$ siswa memperoleh skor minimal 70, dan siklus II 86,21\% siswa memperoleh skor minimal 70. Kesimpulan dari penelitian ini adalah hasil analisis kesalahan tata bahasa dan kosakata yang digunakan sebagai landasan pembelajaran menulis melalui self-editing and selfcorrecting terbukti mampu meningkatkan kemampuan menulis bahasa Inggris siswa.
\end{abstract}

Kata Kunci: analisis kesalahan, tata bahasa dan kosakata, self-editing and self-correcting, kemampuan menulis. IMPROVING THE STUDENTS ENGLISH WRITING SKILL THROUGH SELF-EDITING AND
SELF-CORRECTING BASED ON GRAMMATICAL AND VOCABULARY ERROR ANALYSIS

\begin{abstract}
This study aims to improve students' English writing skills through self-editing and selfcorrecting based on grammar and vocabulary error analysis. This is calssroom action research. The data were collected through observation and test techniques from 28 students. The research was carried out collaboratively in two cycles. Each cycle consists of two actions. Each action consists of planning, implementation, observation, and reflection. After the self-editing and self-correcting action in two cycles, there is an increase in students' English writing skills. The improvement of students' writing skills can be seen from the difference in the error analysis in pre-action, first and second cycle action. The results of pre-action analysis show that 29,16\% of students get 70 as a minimum score. After the implementation of cycle I, it is found that $60 \%$ of students get 70 as a minimum score, and in the second cycle, it is found that $86,21 \%$ of students get 70 as a minimum score. The conclusion of this research is the analysis of grammatical errors and vocabulary that is used as the basis for studying writing through self-editing and self-correcting can improve the students' English writing skills.
\end{abstract}

Keywords: error analysis, grammar and vocabulary, self-editing and self-correcting, writing skills.

How to Cite: Obisuru, M., \& Purbani, W. (2016). Kemampuan menulis bahasa Inggris siswa melalui selfediting and self-correcting berdasarkan analisis kesalahan gramatikal dan kosakata. LingTera, 3(1), 51-59. doi:http://dx.doi.org/10.21831/lt.v3i1.8473

Permalink/DOI: http://dx.doi.org/10.21831/lt.v3i1.8473 


\title{
LingTera, 3 (1), May 2016 - 52
}

\author{
Mathelda Obisuru, Widyastuti Purbani
}

\section{PENDAHULUAN}

Menulis adalah salah satu keterampilan yang produktif dalam mempelajari bahasa. Kegiatan menulis berbeda dengan kegiatan mendengar, berbicara, dan membaca, karena dalam menulis ada sejumlah aspek bahasa yang harus dipatuhi untuk bisa menyampaikan ideide, dan aktualisasi diri yang dapat dipahami oleh orang yang membaca. Di samping itu, hasil tulisan dalam bahasa Inggris dapat digunakan sebagai media penyebaran informasi berita atau ilmu pengetahuan yang sesuai dengan perkembangan jaman kepada masyarakat. Salah satu aspek bahasa yang terkandung dalam kegiatan menulis adalah tata bahasa dan kosakata. Ini berarti bahwa menulis bisa memberikan kesempatan yang bagus kepada siswa untuk semakin memperdalam pemahaman tata bahasa mereka.

Menulis merupakan proses kompleks yang memberikan kesempatan kepada penulis untuk mengungkapkan pikiran dan gagasannya menjadi nampak dan nyata. Maka dalam kegiatan menulis, penulis harus terampil memanfaatkan struktur bahasa dan kosakata, karena menulis melibatkan beberapa sub-skills. Beberapa di antaranya adalah terkait dengan akurasi, yaitu menggunakan bentuk yang benar dari bahasa. Menulis yang akurat melibatkan ejaan dengan benar, membentuk huruf dengan benar, menggunakan tanda baca dengan benar, menggunakan tata letak yang benar, memilih kosakata yang tepat, menggunakan tata bahasa dengan benar, menggabungkan kalimat dengan benar dan menyusun paragraf yang benar pula. Ini berarti bahwa kemampuan menulis melibatkan beberapa subskills yang harus diperhatikan dalam pengajaran menulis. Kemampuan menulis ini tidak akan datang dengan sendirinya melainkan melalui praktek dan latihan yang banyak dan teratur. Berdasarkan konsep dasar tersebut, maka keterampilan menulis akan diperoleh siswa melalui proses yaitu dengan cara pelatihan dan praktek. Semakin banyak pelatihan dan praktek, akan semakin besar pula kemungkinan siswa untuk mampu dan senang akan kegiatan menulis.

Pelaksanaan pembelajaran dan pengajaran menulis bahasa Inggris di sekolah masih menemui beberapa permasalahan, baik dari pihak siswa maupun dari pihak guru itu sendiri. Siswa masih banyak menemui permasalahan dalam belajar menulis karena siswa tidak hanya mempelajari hal-hal yang berkaitan dengan cara menulis, struktur organisasi karangan dan isi, tetapi juga berkaitan dengan kemampuan berbahasa Inggris mereka seperti penggunaan tata bahasa, dan pemilihan kata yang tepat dalam suatu tulisan. Disamping itu, masih kurangnya motivasi belajar dari siswa. Hal ini bisa menyebabkan situasi yang tidak mendukung dalam proses pembelajaran, khususnya pembelajaran menulis bahasa Inggris. Dari pihak guru, pemanfaatan waktu belajar mengajar yang kurang proposional dan efektif dapat menyebabkan siswa kurang mempunyai kesempatan untuk mengekspresikan ide-ide dan kreatifitas yang dimiliki mereka dalam proses pembelajaran.

Tata bahasa dan kosakata adalah unsur bahasa yang penting yang harus diperhatikan oleh siswa karena sebagai kunci untuk memahami makna suatu teks. Namun pada kenyataannya, kedua unsur ini menjadi masalah bagi siswa dalam menulis. Siswa belum menguasai tata bahasa dan kosakata bahasa Inggris dengan baik, sebagai akibatnya siswa mengalami kesulitan dalam pembelajaran menulis dan membuat mereka sulit untuk menulis suatu karangan bahasa Inggris yang baik. Fokus penelitian ini adalah tulisan pembelajar berupa karangan nonfiksi sesuai dengan jenis teks yang dipelajari di kelas XI SMA. Kesalahan tata bahasa dan kosakatanya dalam karangan pembelajar tersebut dianalisis setelah itu dilakukan tindakan self-editing and self-correcting berdasarkan hasil analisis kesalahan tersebut.

Pembelajaran self-editing and sel-correcting dipilih peneliti dalam penelitian ini karena treatment ini membuat siswa lebih aktif dalam proses pembelajaran. Siswa dituntut untuk bisa mengedit dan mengoreksi kesalahan-kesalahan mereka sendiri dalam proses pembelajaran. Selain itu, proses self-editing and self-correcting ini juga bisa membantu guru dalam mengurangi beban mengajar yang begitu banyak, karena siswa yang menjadi fokus dalam pembelajaran dan lebih aktif selama proses pembelajaran itu berlangsung. Dengan memberi kepercayaan kepada siswa untuk mengedit dan mengoreksi kesalahan mereka sendiri dapat memotivasi mereka untuk belajar menjadi lebih baik dan meningkat.

\section{METODE}

Penelitian Tindakan Kelas ini bersifat kolaboratif dengan melibatkan guru sebagai kolaborator. Kemmis \& Taggart (1988, p.5) menyebutkan bahwa "The approach is only action research when it is collaborative, though it is important to realise that the action research 


\title{
LingTera, 3 (1), May 2016 - 53
}

\author{
Mathelda Obisuru, Widyastuti Purbani
}

of the group is achieved through the critically examined action of individual group members".

Berdasarkan definisi Penelitian Tindakan

Kelas yang dikemukakan oleh beberapa ahli pada dasarnya penelitian tindakan kelas dimaksudkan untuk melakukan perubahan pada semua diri peserta didiknya. Peneliti memilih jenis penelitian ini karena sepanjang pengamatan peneliti selama menjadi pendidik di SMAN 1 Kalabahi, guru-guru pada SMAN 1 Kalabahi sering melakukan analisis hasil ulangan atau pekerjaan siswa tetapi tidak menggunakan hasil analisis itu sebagai acuan dalam proses pembelajaran untuk meningkatkan hasil belajar siswa, mereka sekedar melakukan analisisdan selesai sampai disitu. Penelitian ini dimulai dengan tahap peencanaan, tindakan, pengamatan, refleksi, dan selanjutnya diadakan perencanaan kembali yang merupakan dasar pemecahan masalah.

Diskusi yang mendalam dengan kolaborator diperlukan untuk mencari masukan, kritik, saran yang besifat membangun untuk memperoleh validitas dari hasil tindakan. Selain validitas, reliabilitas data juga sangat diperlukan dalam penelitian ini sehingga catatan dari kolaborator juga diperlukan untuk mengurangi tingkat kesubjektifan data.

\section{Waktu danTempat Penelitian}

Penelitian ini dilaksanakan di kelas XI bahasa SMAN 1 Kalabahi. Alasannya adalah berdasarkan observasi awal siswa kelas XI bahasa, hasil menulis bahasa Inggris rendah yaitu nilai tertinggi 9,3 terendah 4,0 dan ratarata 6,9 yang belum mencapai standar ketuntasan minimum 7, dan terdapat begitu banyak kesalahan tata bahasa dan kosakata dalam tulisan siswa-siswi tersebut. Waktu yang dibutuhkan untuk menyelesaikan penelitian ini pada semester 2 tahun ajaran 2012/2013, yaitu tepatnya bulan Februari-April 2013.

\section{Subjek dan Karakteristiknya}

Subjek penelitian ini adalah siswa kelas XI bahasa SMAN 1 Kalabahi dengan jumlah siswa 28 siswa. "Jika populasi penelitian kurang dari 100, maka lebih baik diambil secara keseluruhan populasi itu" Arikunto (2002, p.134). Dengan jumlah yang hanya 28 siswa, maka dalam penelitian ini peneliti mengambill keseluruhan siswa menjadi sampel penelitian. Pemilihan subjek penelitian ini didasarkan pada observasi awal siswa kelas XI bahasa mempunyai kesulitan dalam menulis bahasa Inggris sebagai akibatnya nilai menulis bahasa Inggris juga rendah.

\section{Rencana Tindakan}

Berdasarkan hasil pra observasi yang dilakukan peneliti, maka peneliti, guru, dan kolaborator menyusun tahap-tahap perencanaan tindakan dengan mengacu pada desain penelitian kelas yang dikembangkan oleh Kemmis \& Taggart (1990, pp.11-14).

\section{Tahap Perencanaan (Planning)}

Observasi awal dilakukan oleh peneliti dan guru untuk mengidentifikasi permasalahan dalam proses pembelajaran yang didasarkan pada pengalaman guru dalam pembelajaran menulis. Kondisi nyata di SMAN 1 Kalabahi data hasil menulis siswa kelas XI bahasa nilai tertinggi 90 , nilai terendah 25 dengan nilai ratarata 67. Nilai rata-rata tersebut masih dibawah standar ketuntasan belajar minimum yaitu 70 . Berdasarkan observasi tersebut selanjutnya peneliti dan guru berdiskusi untuk menentukan jenis tindakan yangdipandang mampu mengatasi permasalahan yang ditemukan melalui pembuatan Rencana Pelaksanaan Pembelajaran berdasarkan hasil analisis kesalahan, media pembelajaran, dan tes. RPP digunakan sebagai acuan untuk melaksanakan proses pembelajaran sedangkan media pembelajaran digunakan untuk menyampaikan materi pelajaran kepada siswa, sedangkan tes digunakan untuk mengetahui apakah ada peningkatan hasil menulis siswa setelah dilakukan proses pembelajaran berdasarkan analisis kesalahan.

\section{Tahap Pelaksanaan Tindakan}

Dalam tahap pelaksanaan tindakan ini peneliti menerapkan pembelajaran yang berdasarkan analisis kesalahan yang sudah dilakukan yang dituangkan dalam RPP pada pertemuan pertama setelah dilakukan analisis. Setelah tindakan pertama, peneliti memberikan tes dengan menyuruh siswa membuat karangan berdasarkan penjelasan yang sudah dilakukan guru pada proses pembelajaran. Hasil karangan siswa dianalisis lagi untuk melihat kesalahan tata bahasa dan kosakata yang masih dibuat siswa, dan berdasarkan hasil analisis itu, peneliti bersama guru dan kolaborator menyususn RPP lagi untuk melakukan tindakan kedua.

\section{Tahap Pengamatan Tindakan}

Ketika peneliti bersama guru melakukan tindakan, kolaborator mencatat hal-hal yang 


\title{
LingTera, 3 (1), May 2016 - 54
}

\author{
Mathelda Obisuru, Widyastuti Purbani
}

dianggap penting saat proses pembelajaran berlangsung secara sistematis dan terencana dan secara fleksibel dan terbuka. Pengamatan ini bertujuan untuk mengukur sejauh mana pelaksanaan tindakan yang telah direncanakan berjalan sesuai dengan tujuan yang diharapkan dan masalah apa saja yang timbul selama proses pembelajaran berlangsung.

Tahap Refleksi Tindakan

Pada tahap ini, peneliti mengevaluasi tindakan yang telah dilakukan saat menerapkan pembelajaran yang didasarkan pada analisis tata bahasa dan kosakata siswa dalam menulis. Berdasarkan hasil pengamatan dan catatan lapangan yang telah dikumpulkan secara sistematis, peneliti dan kolaborator mendiskusikan hasil tindakan. Hasil refleksi yang berhasil/efektif digunakan kembali pada siklus selanjutnya, dan hasil tindakan yang gagal/tidak efektif akan diubah atau disesuaikan pada RPP untuk digunakan pada siklus selanjutnya.

\section{Teknik dan Instrumen Pengumpulan Data.}

Pengumpulan data merupakan salah satu langkah penting dari prosedur penelitian, data tersebut dianalisis untuk membuat deskripsi dan inferensi penelitian. Data dalam penelitian ini dikumpulkan dari hasil pengamatan, wawancara, catatan lapangan, dan juga hasil tes menulis siswa. Menurut Madya (2009, p.75) data penelitian tindakan diambil dari suatu situasi bersama seluruh unsur-unsurnya. Data penelitian tindakan dapat berbentuk catatan lapangan, catatan harian, transkrip komentar peserta penelitian, rekaman audio, rekaman video, foto dan rekaman/catatan lainnya. Dan untuk untuk memperoleh data-data yang diperlukan dalam penelitian tindakan kelas menggunakan metode sebagai berikut:

\section{Observasi}

Observasi dilakukan peneliti melalui pengamatan secara langsung terhadap proses belajar mengajar untuk melihat dari dekat kegiatan yang dilakukan oleh siswa. Pengamatan difokuskan pada dua kompetensi yaitu kognitif dan afektif yang diperlihatkan melalui hasil belajar siswa dan perilaku siswa. Dalam penelitian ini peneliti berperan sebagai participant observer dimana observer mempunyai hubungan yang akrab dengan pihak yang diamati dalam hal ini siswa.
Wawancara

Wawancara dilakukan melalui wawancara secara mendalam dengan guru kelas dan kolaborator saat peneliti, guru, dan kolaborator berdiskusi untuk menyusun RPP dan bahan ajar. Wawancara dimaksudkan agar memperoleh umpan balik dari proses pembelajaran menulis sebelumnya.

\section{Analisis Dokumen}

Pengumpulan data dengan teknik analisis dokumen digunakan untuk melengkapi dan memperoleh data yang tepat tentang kesalahankesalahan tata bahasa dan kosakata dengan melihat hasil karangan siswa, dan daftar hasil belajar siswa.

\section{Tes Hasil Belajar}

Tes dilakukan unutk memperoleh data hasil belajar siswa baik sebelum dilakukan tindakan maupun setelah dilakukan tindakan pada setiap siklus.

\section{Teknik Analisis Data}

Teknik analisis data yang digunakan ada dua, yaitu kualitatif dan kuantitatif. Analisis data kualitatif dilakukan melalui tahap-tahap reduksi data, paparan data, dan penyimpulan seperti yang dikemukakan oleh Miles dan Huberman (1984, p.21) dengan istilah reduksi data (data reduction), penyajian data (data display), dan penarikan kesimpulan atau verifikasi (conclusion drawing or verification). Analisis data secara kuantitatif dilakukan pada nilai tes awal dan akhir dengan teknik deskriptif kuantitatif secara sederhana, yakni dengan membandingkan nilai rerata, mean dan simpangan baku.

Analisis data yang dilakukan meliputi tiga tahap. Tahap pertama adalah kategorisasi, data yang terkumpul dari pengamatan, hasil tes, dan nilai hasil menulis dikelompokkan menurut pokok permasalahan yang sejenis. Tahap kedua adalah penyajian data, data disajikan secara deskriptif kualitatif. Tahap ketiga adalah pemaknaan dan penyimpulan. Penyimpulan secara induktif yaitu dengan menafsirkan data yang sudah dikelompokkan. Karena penelitian ini tidak terlepas dari proses refleksi pada setiap akhir siklusnya, maka refleksi digunakan untuk melihat hasil analisis dan proses tindakan di dalam kelas. Kemudian, berdasarkan refleksi yang dilakukan oleh peneliti bersama dengan kolaborator, menentukan proses tindak lanjut atau rencana selanjutnya pada siklus berikutnya untuk 
Mathelda Obisuru, Widyastuti Purbani

mencapai tujuan tindakan yaitu meningkatnya kemampuan menulis siswa kelas XI bahasa.

Penarikan kesimpulan didasarkan pada kriteria keberhasilan tindakan yang telah ditetapkan yaitu peningkatan kemampuan menulis siswa dengan meningkatnya hasil tes siswa. Dari hasil analisis data tersebut, akan ditarik kesimpulan secara keseluruhan dengan menyatakan kebenaran hipotesis yang telah ditetapkan.

\section{HASIL DAN PEMBAHASAN}

\section{Pra-tindakan}

Data yang digunakan dalam penelitian pra-tindakan ini dikumpulkan dari 28 karangan berbentuk Spoof yang dibuat siswa kelas XI bahasa SMAN 1 Kalabahi. Berdasarkan hasil pra-tindakan ini ditemukan 256 kesalahan tata bahasa dan kosakata yang dibuat siswa. Seluruh kesalahan tersebut dapat diklasifikasikan ke dalam empat kategori, yaitu; omission, addition, selection, dan misordering, seperti digambarkan dalam Tabel 1.

Tabel 1 Hasil Analisis Pra-Tindakan

\begin{tabular}{cccc}
\hline No & $\begin{array}{c}\text { Klasifikasi } \\
\text { kesalahan }\end{array}$ & $\begin{array}{c}\text { Jumlah } \\
\text { kesalahan }\end{array}$ & $\begin{array}{c}\text { Prosentasi } \\
\text { kesalahan }\end{array}$ \\
\hline 1. & Omission & 83 & $32,42 \%$ \\
2. & Addition & 38 & $14,84 \%$ \\
3. & Selection & 90 & $35,15 \%$ \\
4. & Misordering & 45 & $17,57 \%$ \\
& $\begin{array}{c}\text { Jumlah total } \\
\text { kesalahan }\end{array}$ & 256 & \\
\hline
\end{tabular}

Omission (Penghilangan)

Tabel 2. Ommision

\begin{tabular}{lccc}
\hline No & Jenis kesalahan & $\begin{array}{c}\text { Jumlah } \\
\text { kesalahan }\end{array}$ & Presentasi \\
\hline 1. & Akhiran 'ed' & 31 & $37,34 \%$ \\
2. & Akhiran 'ing' & 19 & $22,89 \%$ \\
3. & 'be' past & 17 & $20,48 \%$ \\
4. & Artikel & 16 & $19,27 \%$ \\
& Jumlah & 83 & \\
\hline
\end{tabular}

Hasil pra-tindakan ini menemukan 5 kesalahan omission yang dibuat siswa, yaitu; omission dari akhiran 'ed' (kata keja bentuk kedua), akhiran 'ing', 'be' (past), article 'a', article 'the'. Total kesalahan omission yang dibuat siswa adalah 83 dengan tingkat kesalahan tertinggi pada penggunaan ' $e d$ ' untuk katakerja bentuk lampau, dan yang terendah adalah kesalahan pada penggunaan article ' $a$ '.
Addition (Penambahan)

Tabel 3. Addition

\begin{tabular}{lccc}
\hline No & $\begin{array}{c}\text { Jenis } \\
\text { kesalahan }\end{array}$ & $\begin{array}{c}\text { Jumlah } \\
\text { kesalahan }\end{array}$ & Presentasi \\
\hline 1. & 'be' & 17 & $44,73 \%$ \\
2. & Preposition & 8 & $21,05 \%$ \\
3. & Suffix 'ing' & 7 & $18,42 \%$ \\
4. & Suffix 'ed' & 3 & $7,89 \%$ \\
5. & Genitive 's' & 3 & $7,89 \%$ \\
& Jumlah & 38 & \\
\hline
\end{tabular}

Hasil pra-tindakan ini menemukan 5 kesalahan addition yang dibuat siswa, yaitu; addition pada 'be', suffix 'ing', suffix 'ed', preposition 'in', 'at', 'to', dan genitive 's'. Total kesalahan addition yang dibuat siswa adalah 38 dengan tingkat kesalahan tertinggi pada penambahan ' $b e$ ', dan yang terendah adalah pada penambahan genitive 's'.

\section{Selection (Pemilihan Kata)}

Tabel 4. Seletion

\begin{tabular}{lccc}
\hline No & $\begin{array}{c}\text { Jenis } \\
\text { kesalahan }\end{array}$ & $\begin{array}{c}\text { Jumlah } \\
\text { kesalahan }\end{array}$ & Presentasi \\
\hline 1. & Verb & 48 & $53,33 \%$ \\
2. & Pilihan kata & 25 & $27,77 \%$ \\
3. & 'be' & 13 & $3.33 \%$ \\
4. & Preposition & 4 & $4,44 \%$ \\
& Jumlah & 90 & \\
\hline
\end{tabular}

Kesalahan pada kategori selection yang ditemukan pada tahap pra-tindakan ini ada 4 jenis kesalahan, yaitu kesalahan penempatan pada 'verb', pilihan kata, penggunaan ' $b e$ ', dan preposition 'in, at, on'. Total kesalahan yang dibuat adalah 90, dengan tingkat kesalahan tertinggi pada penggunaan verb dan yang terendah pada penggunaan preposition.

Misordering (Kesalahan Penempatan)

Kesalahan pada kategori misordering yang ditemukan pada tahap pra-tindakan ini adalah; kesalahan penempatan kata, kesalahan penempatan huruf baik itu pada kata maupun kalimat. Total kesalahan yang dibuat adalah 45 .

\section{Siklus I}

Berdasarkan hasil analisis kesalahan tata bahasa dan kosakata pada pra-tindakan ini, peneliti dan guru bahasa Inggris kelas XI bahasa menyususn rencana tindakan untuk meningkatkan kemampuan menulis bahasa Inggris siswa dengan berusaha mengurangi jumlah kesalahan tata bahasa dan kosakata yang dibuat siswa dalam tulisan mereka. 


\section{Ling Tera, 3 (1), May 2016 - 56}

Mathelda Obisuru, Widyastuti Purbani

Tindakan yang dilakukan dalam proses pembelajaran yaitu self-editing and selfcorrecting. Dalam kegiatan pembelajaran selfediting and self-correcting ini, siswa dituntut untuk bisa mengedit dan mengoreksi kesalahankesalahan mereka sendiri. Pada awal proses pembelajaran guru membagikan kembali hasil tulisan siswa yang sudah ditandai kesalahannya dan menyuruh siswa untuk mengoreksi kesalahan mereka sendiri. Selanjutnya guru menulis beberapa kalimat yang salah tata bahasa dan kosakatanya di papan tulis dan menyuruh siswa untuk memperbaiki kesalahan-kesalahan tersebut sesuai pengetahuan mereka. Setelah selesai bediskusi dan mengoreksi kesalahan-kesalahan mereka sendiri, kemudian guru memberi penegasan kembali tentang bentuk past tense yang digunakan dalam karangan berbentuk spoof tersebut.

Contoh proses pembelajaran:

Guru : "Okay students, now, look at your work sheet and find any grammatical errors that you made! I give you five minutes to do that, and after that we discuss it together."

Siswa: "Okay, Mam."

Setelah waktu lima menit yang diberikan guru kepada siswa untuk mencari kesalahan tata bahasa yang dibuat dalam tulisan mereka dirasa cukup, guru dan siswa mulai membahas kesalahan-kesalahan itu bersama-sama.)

Guru : "Okay class, do you found any grammatical errors?"

Siswa 1: "Ibu, sayadapat "Then we going in Hula'."

Siswa 2: "Ibu, saya punya 'But we are $O K$ '.

Siswa 3: "We going at 9.00 and arrive 09.30"

Siswa 4: "We meet in Bungawan...."

Guru : "Okay students, now let's correct it together."

Setelah hampir semua siswa memberikan contoh-contoh kesalahan yang mereka temukan dalam tulisan mereka, guru mulai membahas kesalahan-kesalahan tersebut.

Guru : "Siapa yang bias memperbaiki kalimat ini; 'Then we going in Hula'

Siswa1: "Bu, kata going dirubah ke bentuk kedua."

Guru : "Siapa yang tahu bentuk kedua dari kata go?"

Siswa 2: "went bu, dan in diganti to, jadinya 'then we went to Hula', bu'
Guru: "Ya betul. Verb going di kalimat tersebut harus menjadi went." Kalimat berikutnya "but we are $O K$ ", bagian mana yang salah dan siapa yang bias perbaiki?

Siswa 3: "Bu, yang salah to be are. Harusnya were bu."

Guru: "Iya betul sekali. Jadi kalimatnya menjadi but we were OK."

Dari contoh yang sudah dibahas ini sekarang ibu berikan waktu lagi kepada kalian untuk berdiskusi secara berpasangan memperbaiki kesalahan dalam tulisan kalian.

Setelah semua langkah tindakan pada siklus I dilakukan, guru dan peneliti memberikan tes menulis yang kedua untuk dianalisis kesalahan tata bahasa dan kosakatanya, dan untuk dijadikan dasar dalam proses pembelajaran self-editing and self-correcting pada siklus II.

Hasil Siklus I

Tabel 5.Hasil Analisis Siklus Pertama

\begin{tabular}{lccc}
\hline No & $\begin{array}{c}\text { Klasifikasi } \\
\text { kesalahan }\end{array}$ & $\begin{array}{c}\text { Jumlah } \\
\text { kesalahan }\end{array}$ & $\begin{array}{c}\text { Prosentasi } \\
\text { kesalahan }\end{array}$ \\
\hline 1. & Omission & 31 & $19,87 \%$ \\
2. & Addition & 41 & $26,28 \%$ \\
3. & Selection & 61 & $39,10 \%$ \\
4. & Mis-ordering & 23 & $14,74 \%$ \\
& $\begin{array}{c}\text { Jumlah total } \\
\text { kesalahan }\end{array}$ & 156 & \\
\hline
\end{tabular}

Omission (Penghilangan)

Tabel 6. Ommision

\begin{tabular}{lccc}
\hline No & Jenis kesalahan & $\begin{array}{c}\text { Jumlah } \\
\text { kesalahan }\end{array}$ & Presentasi \\
\hline 1. & 'be' past & 10 & $32,25 \%$ \\
2. & Artikel & 10 & $32,25 \%$ \\
3. & Akhiran 'ed' & 6 & $19,35 \%$ \\
4. & Akhiran 'ing' & 5 & $16,12 \%$ \\
& Jumlah & 31 & \\
\hline
\end{tabular}

Hasil tindakan pertama ini menemukan 4 kesalahan omission yang dibuat siswa, yaitu; omission dari 'be' (past), article ' $a$ ', article 'the', akhiran 'ed' (verb bentuk past), akhiran 'ing'. Total kesalahan omission yang dibuat siswa adalah 31 dengan tingkat kesalahan tertinggi pada penggunaan 'be' untuk bentuk lampau tetapi jumlah kesalahannya lebih rendah dari kesalahan pada hasil pra-tindakan. 
Addition (Penambahan)

Tabel 7. Addition

\begin{tabular}{lccc}
\hline No & $\begin{array}{c}\text { Jenis } \\
\text { kesalahan }\end{array}$ & $\begin{array}{c}\text { Jumlah } \\
\text { kesalahan }\end{array}$ & Presentasi \\
\hline 1. & 'be' past & 26 & $63,41 \%$ \\
2. & Preposition & 11 & $26,82 \%$ \\
3. & Suffix 'ing' & 2 & $4,87 \%$ \\
4. & Genitive 's' & 2 & $4,87 \%$ \\
& Jumlah & 41 & \\
\hline
\end{tabular}

Hasil tindakan pertama ini menemukan 4 kesalahan addition yang dibuat siswa, yaitu; addition pada 'be', preposition 'in', 'at', 'to', suffix 'ing', dan genitive ' $s$ '. Total kesalahan addition yang dibuat siswa adalah 41 dengan tingkat kesalahan tertinggi pada penambahan ' $b e$ ', dan yang terendah adalah pada penambahan genitive 's'.

Selection (pemilihan)

Tabel 8. Selection

\begin{tabular}{lccc}
\hline No & $\begin{array}{c}\text { Jenis } \\
\text { kesalahan }\end{array}$ & $\begin{array}{c}\text { Jumlah } \\
\text { kesalahan }\end{array}$ & Presentasi \\
\hline 1. & Pilihan kata & 29 & $46,77 \%$ \\
2. & Verb & 26 & $41,93 \%$ \\
3. & 'be' & 5 & $8,06 \%$ \\
4. & Preposition & 2 & $3,22 \%$ \\
& Jumlah & 62 & \\
\hline
\end{tabular}

Kesalahan pada kategori selection yang ditemukan pada tahap tindakan pertama ini adalah; pilihan kata, kesalahan penempatan pada 'verb', 'be', preposition, dengan jumlah total kesalahan terbanyak diantara keempat kategori kesalahan yaitu 62 kesalahan. Tingkat kesalahan tertinggi terjadi pada pilihan kata dalam suatu kalimat.

\section{Misordering (Kesalahan Penempatan)}

Kesalahan pada kategori misordering yang ditemukan pada tahap tindakan pertama ini adalah; kesalahan penempatan kata, kesalahan penempatan huruf baik itu pada kata maupun kalimat. Total kesalahan yang dibuat adalah 23 .

\section{Siklus II}

Setelah guru dan peneliti menganalisis kesalahan tata bahasa dan kosakata yang dibuat siswa dalam tulisan mereka pada tes menulis kedua, guru dan peneliti menyusun rencana tindakan untuk dilakukan dalam proses pembelajaran pada siklus II. Seperti pada siklus I, pada siklus II pembelajaran self-editing and selfcorrecting dilakukan berdasarkan hasil analisis kesalahan yang sudah dibuat. Siswa diminta untuk mengoreksi kesalahan tata bahasa dan kosakata yang telah mereka buat pada tulisan merekadi tes menulis kedua.

Proses pembelajaran pada tindakan pertama dan kedua dalam siklus II ini berlangsung lebih aktif dan kondusif karena sebagian besar siswa sudah mulai bisa unuk mengedit dan mengoreksi kesalahan mereka sendiri. Pada awal kegiatan pembelajaran, setelah guru menyegarkan kembali ingatan siswa tentang bentuk past tense, guru membagikan hasil tulisan siswa pada tes menulis kedua (tes menulis setelah siklus I) dan menyuruh siswa untuk mencari dan menemukan kesalahan-kesalahan tata bahasa dan kosakata yang sudah mereka buat dalam tulisan mereka. Setelah waktu yang diberikan guru untuk menemukan kesalahan selesai, guru bersama siswa berdiskusi dan mengoreksi kesalahan-kesalahan tersebut. Dalam diskusi tersebut, siswa yang menngoreksi kesalahan mereka sendiri guru tetap berperan sebagai fasilitator dan hanya memberikan penguatan serta penegasan pada jawaban-jawaban siswa.

Proses pembelajaran self-editing and selfcorrecting pada siklus II, terlihat siswa lebih bersemangat dan aktif. Hampir seluruh siswa sudah bisa mengoreksi keslahan mereka sendiri. Ada beberapa siswa saja yang belum bisa mengoreksi sendiri dan guru bersama peneliti memberikan bimbingan dan pemahaman secara khusus kepada mereka.Guru mengajak mereka untuk duduk berkelompok dan guru meminta mereka untuk membandingkan kalimat yang mereka tulis yang mempunyai persamaan tata bahasa dengan contoh kalimat yang ada dalam bahan ajar. Dengan cara begitu, siswa yang masih belum bisa mengoreksi kesalahan mereka sendiri menjadi tahu kesalahan yang telah mereka buat dan bisa memperbaiki kesalahan mereka berdasarkan contoh yang mereka lihat di bahan ajar. Pada akhir tindakan kedua, guru kembali menegaskan tentang bentuk past tense yang digunakan dalam teks spoof dan kemudian memberikan tes menulis ketiga.

Contoh proses pembelajaran:

Guru: "Okay students, now look at the Following examples on the whiteboard and try to correct the underlined words!"

1. We were laugh

2. I'm see a beautiful bag

3. We bring the equipment we use

4. He took some were important stuff 


\section{LingTera, 3 (1), May 2016 - 58}

Mathelda Obisuru, Widyastuti Purbani

\section{After that we start cook nasi kuning \\ 6. We very happy because to get many fish}

Siswa 1: "Ibu, kalimat nomor 3 saya bisa bu, itu harusnya 'we brought the equipment we used'."

Guru : "Ya, betul sekali. Kata bring dan use dalam kalimat tersebut harus dirubah ke bentuk past." Ayo siapa lagi yang bisa memperbaiki kalimat yang lainnya?

Siswa 2: "Saya bu, kalimat nomor 5 harusnya After that we started cook nasi kuning."

Guru : "Ya, betul. Verb Start dalam kalimat tersebut dirubah ke bentuk kedua atau bentuk past. Bagaimana dengan kata see dan get pada kalimat nomor 2 dan 6 , apakah menjadi seed dan geted?

Siswa :"Iya bu."

Guru : "Coba tolong buka kamus kalian dan lihat betul atau tidak jawaban kalian."

Siswa 3: "Salah bu, kata see menjadi saw dan get menjadi got bu."

Guru : "Benar sekali. See dan get adalah kata kerja tak beraturan, jadi bentuk lampaunya berubah. Ingat anak-anak, ada dua jenis kata kerja, yaitu kata kerja beraturan dan tidak beraturan. Kata kerja yang beraturan bentuk kedua ditambah huruf 'ed', sedangkan kata kerja tidak beraturan bentuk kedua atau lampau berubah. Jadi, tidak semua kata kerja bentuk lampaunya ditambah huruf 'ed', tetapi ada yang berubah bentuknya. Lihat kamus kalian ya.

Siswa : "Iya bu."

Setelah semua langkah tindakan pada siklus II dilakukan, guru dan peneliti memberikan tes menulis yang ketiga untuk untuk dianalisis kesalahan tata bahasa dan kosakata dan untuk mendapatkan hasil akhir dari semua tindakan dalam proses pembelajaran self-editing and self-correcting.

Hasil Siklus II

Tabel 9.Hasil Analisis Siklus Kedua

\begin{tabular}{lccc}
\hline No & $\begin{array}{c}\text { Klasifikasi } \\
\text { kesalahan }\end{array}$ & $\begin{array}{c}\text { Jumlah } \\
\text { kesalahan }\end{array}$ & $\begin{array}{c}\text { Presentasi } \\
\text { kesalahan }\end{array}$ \\
\hline 1. & Omission & 15 & $21,73 \%$ \\
2. & Addition & 13 & $18,84 \%$ \\
3. & Selection & 7 & $10,14 \%$ \\
4. & Misordering & 34 & $49,27 \%$ \\
& $\begin{array}{c}\text { Jumlah total } \\
\text { kesalahan }\end{array}$ & 69 & \\
\hline
\end{tabular}

Omission (Penghilangan)

Hasil siklus kedua ini menemukan 4 kesalahan omission yang dibuat siswa, yaitu; omission dari 'be' (past), article, suffix 'ed', 'ing', preposition.

\section{Addition (Penambahan)}

Hasil siklus kedua ini menemukan 3 kesalahan addition yang dibuat siswa, yaitu; addition pada 'be' past, suffix 'ed', preposition.

\section{Selection (Pemilihan)}

Kesalahan pada kategori selection yang ditemukan pada siklus kedua ini ada 3, yaitu; kesalahan penempatan pada 'verb', 'be' past, pilihan kata, dengan tingkat kesalahan tertinggi pada penggunaan kata kerja bentuk lampau.

\section{Misordering (Kesalahan Penempatan)}

Hasil siklus kedua ini menunjukan tingkat kesalahan tertinggi dari kategori misordering dibandingkan dengan hasil pra-tindakan dan tindakan pertama. Siswa banyak melakukan kesalahan dengan menulis kata yang kurang huruf, salah penempatan huruf, dan juga penempatan kata yang terbalik posisinya, tetapi tidak menghilangkan makna dari kalimat tersebut sehingga tetap dapat dipahami.

Dengan melakukan semua langkah-langkah kegiatan pada tindakan siklus I dan siklus II, sangat membantu siswa dalam menulis karangan bahasa Inggris. Kegiatan proses pembelajaran berlangsung dengan baik dan efektif karena siswa sudah mampu menemukan kesalahan mereka sendiri dan juga sudah mampu untuk mengoreksi atau memperbaikinya sendiri dalam tulisan mereka.

Penilaian yang dilakukan pada hasil tes menulis kedua (pada akhir siklus I) dan hasil tes menulis ketiga (pada akhir siklus II) menunjukkan adanya perbaikan dan peningkatan dalam kemampuan menulis siswa. Pada tes menulis kedua, sudah lebih dari 50\% siswa yang memperoleh nilai diatas standar ketuntasan minimum 70. Hal ini berbeda dengan hasil tes menulis pertama (pra-tindakan) dimana kurang dari $50 \%$ siswa yang memperoleh nilai diatas standar ketuntasan minimum. Pada tes menulis ketiga, terlihat hampir semua siswa sudah bisa mencapai nilai diatas standar ketuntasan minimum, yaitu lebih dari $80 \%$ siswa sudah memperoleh nilai 70 .

Berdasarkan hasil tes menulis yang dilakukan setelah langkah-langkah pembelajaran dalam siklus I dan siklus II dapat disimpulkan 


\section{LingTera, 3 (1), May 2016 - 59}

Mathelda Obisuru, Widyastuti Purbani

bahwa pemanfaatan data analisis kesalahan tata bahasa dan kosakata, serta strategi pembelajaran yang benar dalam proses pembelajaan menulis di kelas dapat meningkatkan kemampuann menulis bahasa Inggris siswa.

\section{SIMPULAN DAN SARAN}

Berdasarkan hasil analisis kenyataan tindakan yang telah dilaksanakan dan dilaporkan dalam dua siklus, dimana proses pembelajaran melalui self-editing and self-correcting baik pada tindakan siklus I dan siklus II yang didasarkan pada analisis kesalahan tata bahasa dan kosakata yang dibuat oleh guru dan peneliti dapat disimpulkan bahwa telah terjadi perubahan yang lebih baik dalam kemampuan menulis siswa dibandingkan dengan sebelum dilakukan tindakan. Perubahan terhadap kemampuan menulis siswa didasarkan pada hasil analisis tulisan siswa yang semakin baik pada siklus I dan II.

Berdasarkan hasil analisis kesalahan tata bahasa dan kosakata pada pra-tindakan, dan hasil analisis setelah dilakukan tindakan pada siklus I dan siklus II, penulis menyarankan: (1) Perlu adanya analisis kesalahan tata bahasa dan kosakata yang dibuat guru setelah pembelajaran menulis; (2) Guru pengajar bahasa Inggris harus merencanakan proses pembelajaran yang efektif, efisien dan menyenangkan bagi siswa; (3) Guru pengajar bahasa Inggris dalam proses pembelajaran untuk meningkatkan kemampuan menulis siswa perlu melakukan analisis kesalahan tata bahasa dan kosakata, serta menggunakan hasil analisis yang dibuat tersebut dalam proses pembelajaran selanjutnya.

\section{DAFTAR PUSTAKA}

Arikunto, S. (2010). Prosedur penelitian suatu pendekatan praktik. Jakarta: Rineka Cipta.

Kemmis, S., \& McTaggart, R. (1990). The action research planner. Australia: Deakin University.

Madya, S. (2006). Teori dan praktik penelitian tindakan (action research). Bandung: Alfabeta.

Miles, M.B. \& Huberman, A.M. (1984). Qualitative data analysis: a source book of new methods. California: SAGE Publications. Inc. 